\title{
1 The development of the global film industry between 2017 and 2018
}

\author{
Xingzhen Niu
}

\section{Interpretation of the global film industry data}

\section{Total global box office}

Global box office: scale and growth

According to statistics from the internationally renowned market research company comScore, in 2018, the global box office totaled US\$41.1 billion, its highest ever record. This was an increase of 1.48 percent compared with that of 2017, but the growth rate slowed down. According to the statistics, in the past ten years, the global box office has continued to grow. The global box office growth rate was 4.02 percent in 2008-2018 (Figure 1.1).

\section{Global box office: regional structural changes}

The data show that benefiting from the double increase in the viewing numbers for movies (1.3 billion), the box office in North America totaled US\$11.9 billion in 2018 (Figure 1.2), a record high in recent years. The Chinese film market had also contributed significantly to the growth of the global box office in 2018. According to the data released by the Chinese National Film Bureau, the total box office of Chinese movies in 2018 was 60.976 billion yuan, and the number of people watching movies reached 1.72 billion, up 9 percent and 6 percent respectively compared with that of 2017.

From the regional perspective, the box office (US\$11.9 billion) in North America (hereafter referred to as the US and Canada) increased by 7 percent in 2018 compared with 2017, while the total box office in other regions (US\$29.2 billion) declined 1 percent, accounting for 71 percent of the global box office, which is down 2 percent from 2017. Of them, the box office in the Asia-Pacific region (US\$16.7 billion) was up 5 percent from 2017, and the main driving force is China; the box office in Europe, the Middle East and Africa (EMEA) was down 3 percent from 2017, mainly due to the decline in box office in Germany and Russia. After a 21 percent increase in 2017, the box office in Latin America fell by 21 percent in 2018, and in Brazil fell 


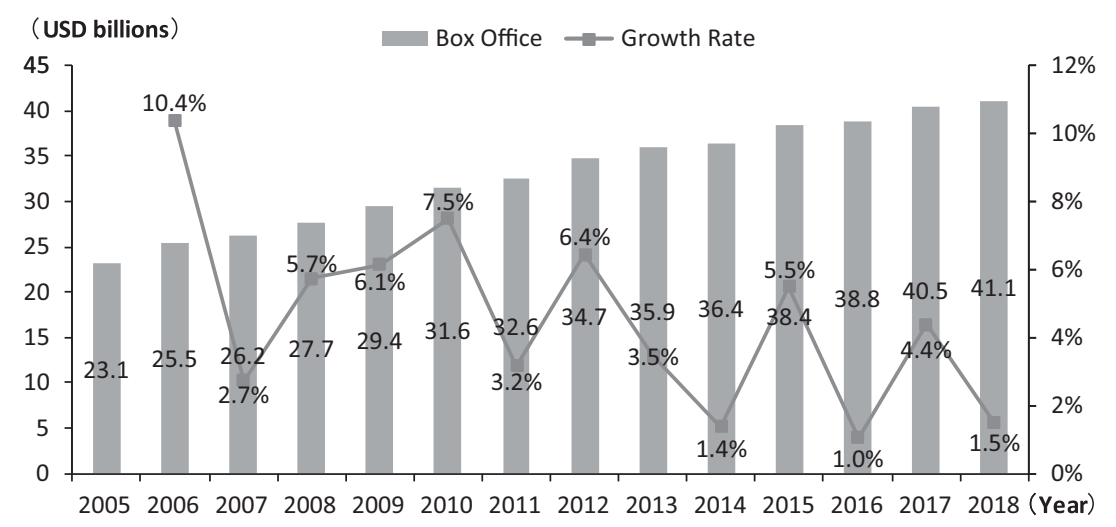

Figure 1.1 Global box office and growth rate, 2005-2018.

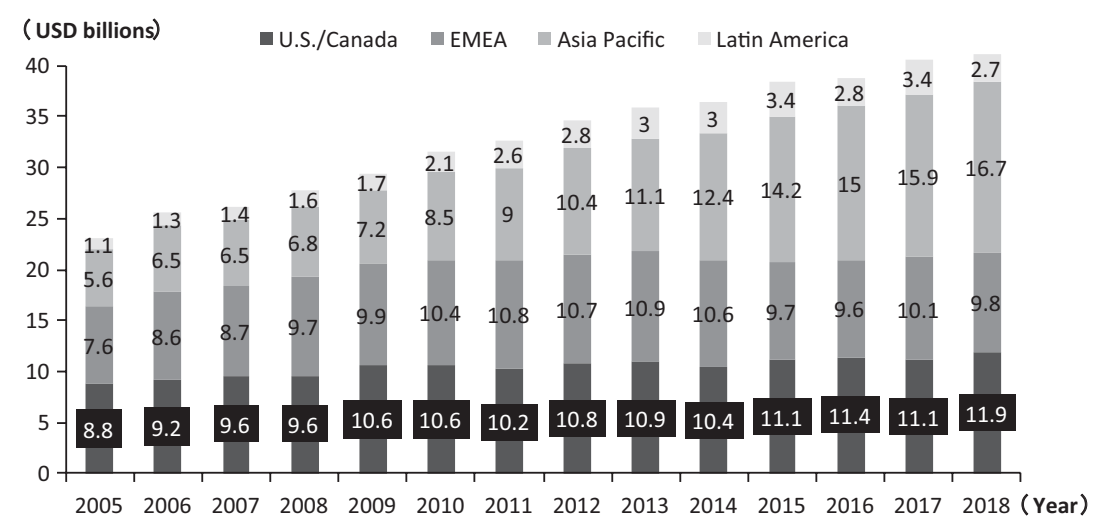

Figure 1.2 Regional structure of the global box office, 2005-2018.

by 22 percent on a yearly basis, and the currency depreciation in Argentina (-41 percent) and Mexico ( -2 percent) further intensified an overall decline in the box office in Latin America. In terms of long-term development, the growth of the box office in North America and Europe, the Middle East and Africa has slowed down and even stagnated in recent years, while the AsiaPacific region has shown rapid growth. Emerging markets are becoming the driving force for the global box office growth. Since the Asia-Pacific region replaced North America in 2013 as the world's largest ticket market, the gap between the Asia-Pacific region and North America has grown. In terms of regional structure, in 2018, the box office in the Asia-Pacific region accounted for 40.6 percent of the global box office, North America accounted for 


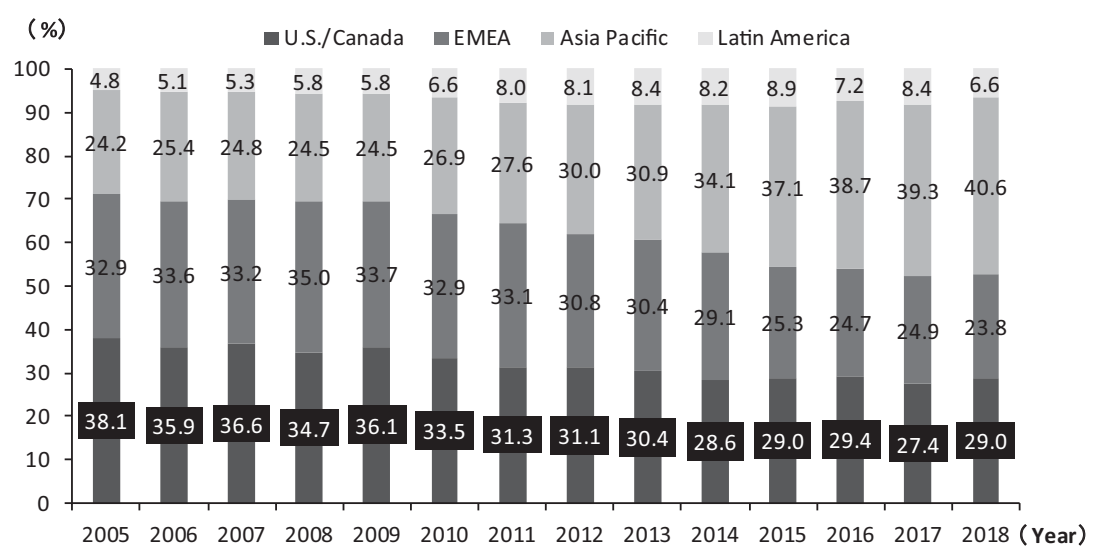

Figure 1.3 Regional structure share of global movie box office, 2005-2018.

29 percent, Europe, the Middle East and Africa accounted for 23.8 percent, and Latin America accounted for 6.6 percent (Figure 1.3).

\section{Global box office: changes in terms of national structure}

In 2018, the top three global box office markets (excluding the US and Canada) were China (US\$9 billion, including online ticketing fees), Japan (US\$2 billion) and the United Kingdom (US\$1.7 billion), the same as 2017; Malaysia and the United Arab Emirates replaced Argentina and Turkey, to be ranked in the top 20. In recent years, the pattern of the world's major film markets has also undergone major changes, mainly in the emerging markets represented by the BRICS countries (Brazil, Russia, India, China and South Africa). The previous mature markets are mostly showing slow growth, stable stagnation and even decline. At present, North America is still the world's largest film market. China has replaced Japan as the second largest box office market in the world since 2012. It is now approaching the size of the North American market. China and the United States jointly dominate the global film market. The "G2 pattern" is increasingly appearing (the North American and Chinese markets account for more than 50 percent of the global box office). In 2011, the top ten box office countries (excluding North America) were Japan, China, France, Britain, India, Germany, Russia, Australia, South Korea and Italy. In 2018, the top ten box office countries (excluding North America) were China, Japan, Britain, South Korea, France, India, Germany, Australia, Russia and Brazil. The top ten countries in the total box office from 2011 to 2018 (excluding North America) were China, Japan, Britain, France, India, South Korea, Germany, Russia, Australia and Brazil (Table 1.1, Figure 1.4). 


\section{Xingzhen Niu}

Table 1.1 Top 10 countries with the largest box office revenue, 2011-2018 (excluding North America) (hundred million)

\begin{tabular}{lllllllllll}
\hline Number & Country & 2011 & 2012 & 2013 & 2014 & 2015 & 2016 & 2017 & 2018 & Total \\
\hline 1 & China & 20 & 27 & 36 & 48 & 68 & 66 & 79 & 90 & 434 \\
2 & Japan & 23 & 24 & 24 & 20 & 18 & 20 & 20 & 20 & 169 \\
3 & United & 17 & 17 & 17 & 17 & 19 & 17 & 16 & 17 & 137 \\
& Kingdom & & & & & & & & & \\
4 & France & 20 & 17 & 16 & 18 & 14 & 16 & 15 & 16 & 132 \\
5 & India & 14 & 14 & 15 & 17 & 16 & 19 & 16 & 15 & 126 \\
6 & South Korea & 11 & 13 & 14 & 16 & 15 & 15 & 16 & 16 & 116 \\
7 & Germany & 13 & 13 & 13 & 13 & 13 & 11 & 12 & 10 & 98 \\
8 & Russia & 12 & 12 & 14 & 12 & 8 & 7 & 10 & 9 & 84 \\
9 & Australia & 11 & 12 & 11 & 10 & 9 & 9 & 9 & 9 & 80 \\
10 & Brazil & - & 8 & 9 & 8 & 7 & 7 & 9 & 7 & 55 \\
\hline
\end{tabular}

Source: Compiled by the author from data in IHS Markit, etc., cited by Motion Picture Association of America.

Note: Brazil was not among the top ten in 2011, the box office there is unknown; in 2018, the Chinese box office includes online ticketing fees.

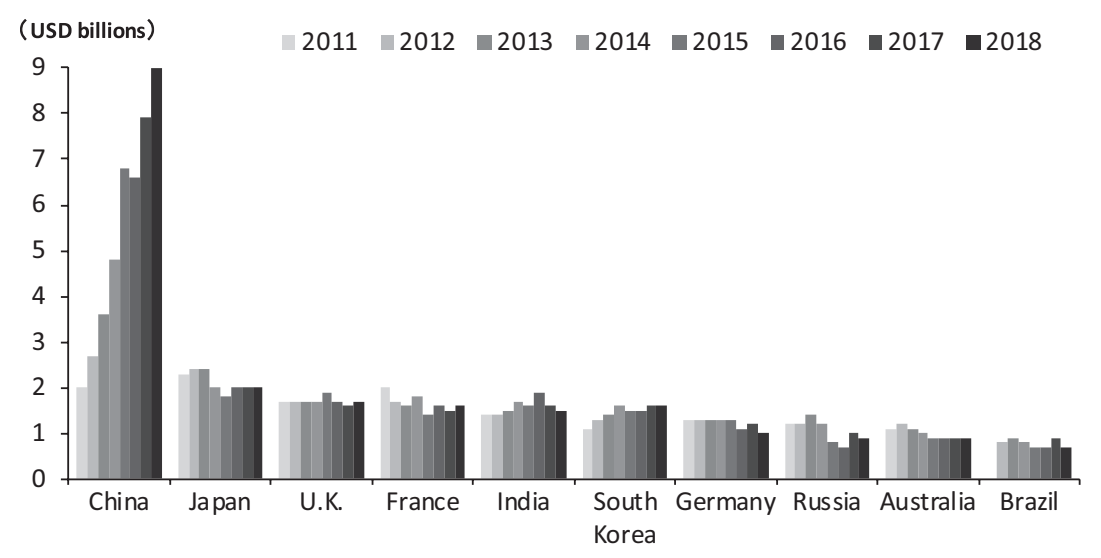

Figure 1.4 Top ten countries with global box office receipts, 2011-2018 (excluding North America).

\section{Global film production output}

According to UNESCO's statistics, total global film production in 2017 was 6,442 films, a decrease of 27.08 percent compared with 2016, and a compound growth rate of 1.24 percent compared with 5,559 films in 2005 (Figure 1.5). From a global perspective, 2,324 films were produced in Asia in 2017, accounting for 36.08 percent of the total; in Europe, 2419 films, accounting for 37.55 percent; in North America, 978 films, accounting for 15.18 percent; in 


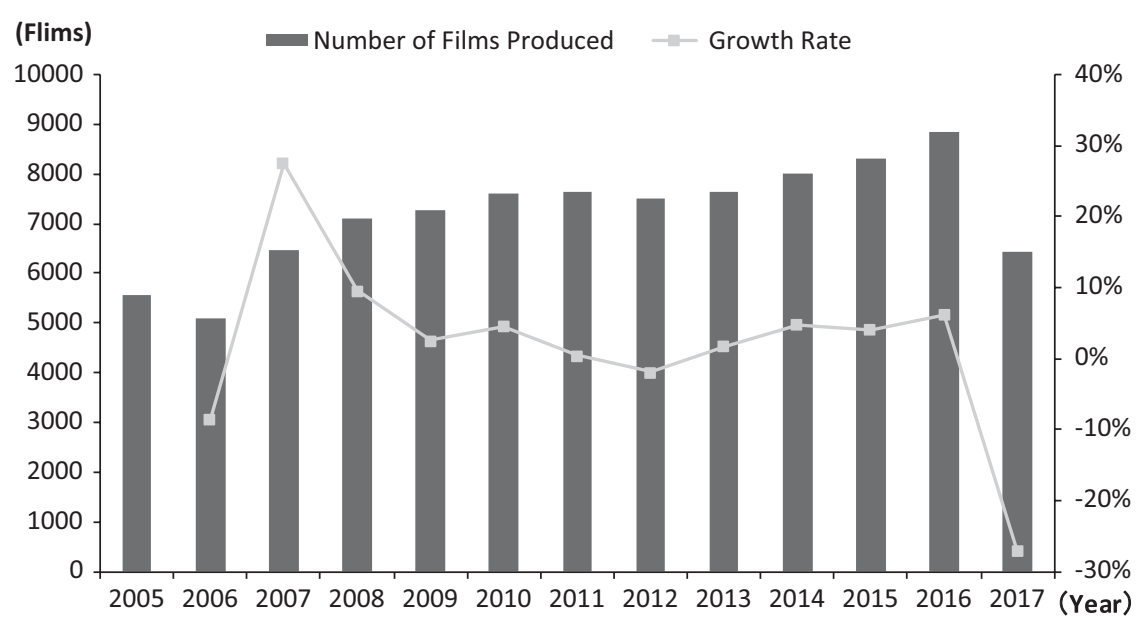

Figure 1.5 Global film production and growth rate, 2005-2017.

Table 1.2 Global film production by continent, 2005-2017

\begin{tabular}{lrrrrrrrrrrrrr}
\hline Continent & 2005 & 2006 & 2007 & 2008 & 2009 & 2010 & 2011 & 2012 & 2013 & 2014 & 2015 & 2016 & 2017 \\
\hline Asia & 2278 & 2498 & 2794 & 3038 & 3063 & 3052 & 3145 & 3823 & 3828 & 3993 & 4174 & 4619 & 2324 \\
Europe & 1368 & 1454 & 1508 & 1803 & 1897 & 2069 & 2047 & 2184 & 2213 & 2326 & 2379 & 2492 & 2419 \\
North & 815 & 826 & 966 & 937 & 917 & 991 & 1001 & 961 & 965 & 910 & 948 & 951 & 978 \\
$\quad$ America & & & & & & & & & & & & & \\
South & 132 & 175 & 198 & 247 & 247 & 253 & 283 & 316 & 398 & 448 & 504 & 502 & 523 \\
$\quad$ America & & & & & & & & & & & & & \\
Africa & 938 & 98 & 980 & 1035 & 1099 & 1189 & 1105 & 163 & 178 & 247 & 254 & 205 & 123 \\
Oceania & 28 & 34 & 37 & 45 & 60 & 58 & 68 & 53 & 51 & 72 & 62 & 65 & 75 \\
Total & 5559 & 5085 & 6483 & 7105 & 7283 & 7612 & 7649 & 7500 & 7633 & 7996 & 8321 & 8834 & 6442 \\
\hline
\end{tabular}

Source: UNESCO, available at: (http://data.uis.unesco.org/), accessed February 2019.

South America, 523 films, accounting for 8.12 percent; in Africa, 123 films, accounting for 1.91 percent; and in Oceania, 75 films, accounting for 1.16 percent (Table 1.2). Looking at the compound growth rate from 2005 to 2017, South America's compound growth rate (12.16 percent) was the highest, followed by Oceania (8.56 percent), Europe (4.86 percent), North America (1.53 percent), and Asia (0.17. percent), but Africa was (-15.57 percent).

Looking at the developed countries or regions, the OECD (the Organisation for Economic Co-operation and Development) and the BRICS countries have different rates of growth in both film production and global share. The film production of 43 developed countries or regions increased from 2,518 films in 2005 to 3,499 films in 2017, with the proportion increasing from 45.30 percent to 54.32 percent; the film production of the 36 OECD member 


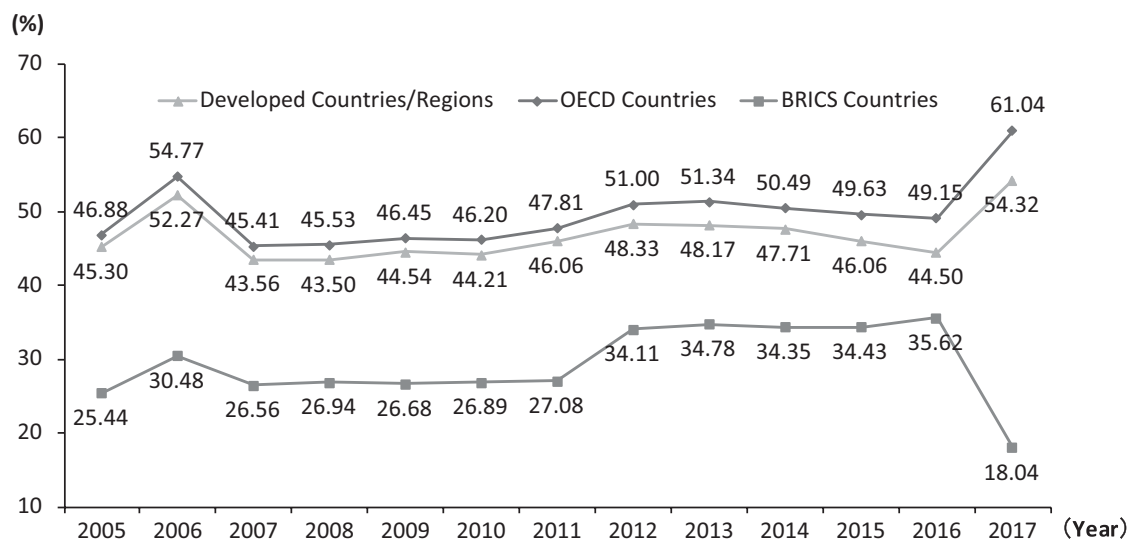

Figure 1.6 Film production proportion of global economies, 2005-2017.

countries increased from 2,606 films in 2005 to 3,932 films in 2017, with the proportion increasing from 46.88 percent to 61.04 percent; film production in the BRICS countries dropped from 1,414 films in 2005 to 1,162 films in 2017, and the proportion dropped from 25.44 percent to 18.04 percent (Figure 1.6). It should be noted that due to the lack of data from Nigeria in 2006 and 2012-2017, the proportion of other countries or regions has been increased. Excluding this factor, in other years, the developed countries or regions, the OECD and BRICS countries have increased to varying degrees compared to 2005.

From 2005 to 2017, the top ten film production countries were: India, the United States, China, Japan, Nigeria, the United Kingdom, France, Germany, Spain, and South Korea. In 2017, the number of US films produced was 791, accounting for 12.28 percent of the total, with a compound growth rate of 0.48 percent in the past 12 years; China produced 874 films, 13.57 percent, compound growth rate of 10.63 percent; Japan produced 594 films, accounting for 9.22 percent. The compound growth rate was 4.36 percent; the UK produced 285 films, accounting for 4.42 percent, and the compound growth rate was 8.59 percent; France produced 300 films, accounting for 4.66 percent, and the compound growth rate was 2.26 percent; Germany produced 226 films, accounting for 3.51 percent, compound growth rate was 4.47 percent; Spain produced 255 films, accounting for 3.96 percent, with a compound growth rate of 1.88 percent; in 2016, India's film production was 1,986 films, with a compound growth rate of 6.05 percent; South Korea's film production in 2016 was 339 films, with a compound growth rate of 13.16 percent; Nigerian film production increased from 872 films in 2005 to 997 films in 2011, accounting for 13.03 percent to 15.69 percent, with a compound growth rate of 2.26 percent (Figure 1.7). 


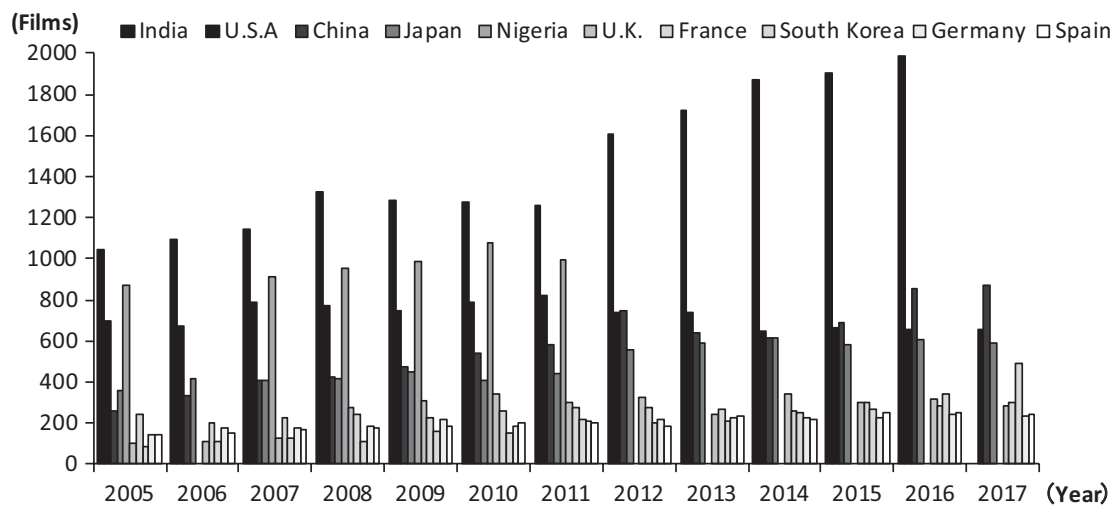

Figure 1.7 Top ten film production countries, 2005-2017.

\section{The spectacle movie boosts the experience economy}

\section{Visual pleasure is the essential nature of film}

The visual pleasure is the essential nature of film. The history of the spectacle film can be traced back to hundreds of short films by Georges Méliès, and western film scholars have constructed a binary pattern of "narrative spectacle," in which the original meaning of spectacle refers to "the rare and special, unexpected, unpredictable sights and things that are directly perceived by the visual (or audiovisual)." In this sense, all kinds of natural or human characters and storylines that transcend the scope of people's experience can be regarded as movie wonders. There are four main types of spectacle films: (1) action spectacle; (2) body spectacle; (3) speed spectacle; and (4) scene spectacle (Table 1.3). The true movie spectacle was gradually developed along with advances in electronic technology. Especially since the 1970s, with the wide application of computer graphics technology in the film industry, a large number of special effects and strange scenes have become common in science fiction movies, and action and disaster movies. From Jurassic Park and Titanic to Avatar, the extraordinary visual representation manipulated by CGI and special effects highlights the infinite charm of film.

\section{Movie entertainment: an important consumption method in the era of the experience economy}

American scholars B. Joseph Pine II and James H. Gilmore proposed that, after the era of the agricultural economy, the industrial economy, and the service economy, human society has now entered the era of the experience economy (Chunjuan, 2015). The experience economy includes four types: (1) 
Table 1.3 Four main types of spectacle films

\begin{tabular}{|c|c|c|}
\hline Type & Meaning & Applications \\
\hline $\begin{array}{l}\text { Action } \\
\text { spectacle }\end{array}$ & $\begin{array}{l}\text { Thrilling and exciting } \\
\text { action attracts people's } \\
\text { attention }\end{array}$ & $\begin{array}{l}\text { Cowboy shoot-outs in Westerns, gun } \\
\text { battles and stunts in detective movies, } \\
\text { strange action design in the science } \\
\text { fiction film, Chinese Kung Fu, etc. }\end{array}$ \\
\hline $\begin{array}{l}\text { Body } \\
\text { spectacle }\end{array}$ & $\begin{array}{l}\text { Apply various film } \\
\text { means to show human } \\
\text { bodies }\end{array}$ & Female bodies; male masculinity \\
\hline $\begin{array}{l}\text { Speed } \\
\text { spectacle }\end{array}$ & $\begin{array}{l}\text { Create special visual } \\
\text { effects by speed }\end{array}$ & $\begin{array}{l}\text { The speed or rhythm of the lens, the speed } \\
\text { of the object or of the human body, and } \\
\text { the superposition and combination of } \\
\text { the two speeds }\end{array}$ \\
\hline $\begin{array}{l}\text { Scene } \\
\text { spectacle }\end{array}$ & $\begin{array}{l}\text { Unique scenes of } \\
\text { various sceneries and } \\
\text { environments }\end{array}$ & $\begin{array}{l}\text { Natural spectacle, human spectacle, virtual } \\
\text { spectacle }\end{array}$ \\
\hline
\end{tabular}

entertainment experience; (2) educational experience; (3) escape experience; and (4) aesthetic experience. The entertainment experience is a kind of joy and inspiration brought about by participating in or interacting with others. With the development of society and technology, ways of leisure and entertainment vary. With the continuous evolution of the entertainment economy, the entertainment experience has gradually been developed, and an experience economy based on the entertainment experience has emerged. The entertainment experience refers to an economic situation once society has developed to a certain stage, when directly or indirectly the public is entertained by products or services, essentially a manifestation of the spiritual value of material consumption. The core of the entertainment experience is to create the innermost extreme experience. The essence of market competition is actually to compete for people's leisure time.

Movies are the product of modern technology and digital technology has had a major impact on film. Digital production, the distribution and projection technology have greatly enhanced the audiovisual experience of film, especially the special effects films with 4D and 5D special effects technology to bring the audience a new sense of entertainment (in a variety of senses), such as sounds, sight, smell, touch and movement. The spectacle characteristics of film have further promoted the transformation of the film industry from "watching" to "experiencing."

Digital movies made with computer graphics, with their extraordinary spectacle and shocking effects, strong entertainment experience and unique appeal, win extraordinarily high box office receipts around the world. Since the 1990s, Terminator 2, Jurassic Park, Independence Day, Titanic, the Star Wars series, and the Harry Potter series have been popular for their digital effects, the Lord of the Rings series, the Pirates of the Caribbean series, Avatar, 
the Avengers series, Transformers 4, Captain America 3: Civil War and others, plus special effects blockbusters, and animated films such as Aladdin, The Lion King, Toy Story, Shrek 2, Toy Story 3, and Frozen have become the global box office champions with a strong entertainment experience and moneyattracting ability (Table 1.4).

\section{Sci-fi movies become mainstream movie types}

According to the statistics, from 1982 to 2018, North America released a total of 15,827 movies, with a total box office of US\$271.168 billion, and an average box office of about US\$17.1333 billion for each movie. In terms of genre, they were mostly dramas $(2,110)$, comedies $(1,997)$, documentaries $(1,861)$, and action films (971), with a number of foreign language films $(1,814)$ accounting for 55.30 percent of the total. In terms of box office, the best performers were action movies (US\$52.646 billion), comedies (US $\$ 37.15$ billion), animations (US\$27.16 billion), science fiction (US\$22.619 billion) and feature films (167.87 billion), accounting for 57.64 percent of the overall box office. From the average box office (by genre), sci-fi (US\$56.5229 million), action movies (US\$53.9099 million), animations (US\$50.3044 million), fantasy (US\$49.2617 million) and adventure (US\$41.6479 million) were the top (Figure 1.8). It can be seen that the number of dramas, documentaries and foreign language films was large, but the performance was average; the number of comedies and action movies was not only large, but also brought in great box office receipts; the number of science fiction films, animations and adventure films was small, but the box office performance was better.

The number of sci-fi films and fantasy films has grown steadily, with numbers of 23 and 21 in 2018 respectively; the number of animations has increased significantly (73 in 2018). In terms of the box office, animations brought in US $\$ 1.617$ billion, and the average box office receipt was US\$22.1563 million; sci-fi and fantasy films achieved US\$704 million and US\$481 million, respectively, with an average box office receipt of US\$30.601 million and US\$22.8851 million, respectively (Figure 1.9).

As one of the mainstream film types, sci-fi films enjoy great success at the box office, and the reason can be traced back to the early black-and-white film Le Voyage dans la Lune by Georges Méliès in the early twentieth century. In the course of more than one hundred years of development, sci-fi films have stimulated philosophical thinking about human existence and aroused environmental concern among audiences for the future survival of the planet and future human development through profound sci-fi concepts, while also relying on film technology to create amazing visual wonders, with astounding artistic and great commercial value.

As early as the 1920s, the golden age of American science fiction, sci-fi movies had made great progress, gradually changing from low-level popular B-class films to A-level films with unique and elegant content and form. In the late 1970s, with the emergence of the Star Wars series, sci-fi movies, with 
Table 1.4 Global box office champions, 1989-2018

\begin{tabular}{|c|c|c|c|c|c|}
\hline Year & Title & Distributor & $\begin{array}{l}\text { Global box } \\
\text { office }(10,000)\end{array}$ & $\begin{array}{l}\text { Proportion of } \\
\text { North America (\%) }\end{array}$ & $\begin{array}{l}\text { Proportion of } \\
\text { international (\%) }\end{array}$ \\
\hline 1989 & $\begin{array}{l}\text { Indiana Jones and the Last } \\
\text { Crusade }\end{array}$ & Paramount & 47420 & 41.6 & 58.4 \\
\hline 1990 & Ghost & Paramount & 50570 & 43.0 & 57.0 \\
\hline 1991 & Terminator $2 *$ & Sony Columbia & 51980 & 39.4 & 60.6 \\
\hline 1992 & Aladdin & Disney Buena Vista International & 50410 & 43.1 & 56.9 \\
\hline 1993 & Jurassic Park* & Universal & 98380 & 36.3 & 63.7 \\
\hline 1994 & The Lion King & Disney Buena Vista International & 85860 & 36.4 & 63.6 \\
\hline 1995 & Toy Story & Disney Buena Vista International & 37360 & 51.3 & 48.7 \\
\hline 1996 & Independence Day* & Fox & 81740 & 37.5 & 62.5 \\
\hline 1997 & Titanic* & Paramount & 212890 & 28.2 & 71.8 \\
\hline 1998 & Armageddon & Disney Buena Vista International & 55370 & 36.4 & 63.6 \\
\hline 1999 & $\begin{array}{l}\text { Star Wars: Episode I - The } \\
\text { Phantom Menace }\end{array}$ & Fox & 98360 & 43.8 & 56.2 \\
\hline 2000 & Mission: Impossible II & Paramount & 54640 & 39.4 & 60.6 \\
\hline 2001 & $\begin{array}{l}\text { Harry Potter and the Sorcerer's } \\
\text { Stone }\end{array}$ & Warner Bros. & 97480 & 32.6 & 67.4 \\
\hline 2002 & $\begin{array}{l}\text { The Lord of the Rings: The } \\
\text { Two Towers* }\end{array}$ & New Line Cinema & 92330 & 36.8 & 63.2 \\
\hline 2003 & $\begin{array}{l}\text { The Lord of the Rings: The } \\
\text { Return of the King* }\end{array}$ & New Line Cinema & 111910 & 33.7 & 66.3 \\
\hline 2004 & Shrek 2 & Dream Works Studios & 91980 & 48.0 & 52.0 \\
\hline 2005 & $\begin{array}{l}\text { Harry Potter and the Goblet of } \\
\text { Fire }\end{array}$ & Warner Bros. & 89690 & 32.30 & 67.70 \\
\hline 2006 & $\begin{array}{l}\text { Pirates of the Caribbean: } \\
\text { Dead Man's Chest* }\end{array}$ & Disney Buena Vista International & 106620 & 39.70 & 60.30 \\
\hline
\end{tabular}


2007 Pirates of the Caribbean: At World's End

2008 The Dark Knight

2009 Avatar*

2010 Toy Story 3**

2011 Harry Potter and the Deathly Hallows: Part 2

2012 The Avengers

2013 Frozen**

2014 Transformers: Age of Extinction

2015 Star Wars: The Force Awakens

2016 Captain America: Civil War

2017 Star Wars: The Last Jedi

2018 Avengers: Infinity War
Disney Buena Vista International

Warner Bros.

Fox

Disney Buena Vista International

Warner Bros.

Disney Buena Vista International

Disney Buena Vista International

Paramount

Disney Buena Vista International

Disney Buena Vista International

Disney Buena Vista International

Disney Buena Vista International
96340

32.10

67.90

100300

277720

106700

134150

151880

127650

110410

206820

115330

133250

204650
53.20

27.00

38.90

28.40

41.00

31.40

22.20

45.30

35.40

46.50

33.20
46.80

73.00

61.10

71.60

59.00

68.60

77.80

54.70

64.60

53.50

66.80

Source: www.boxofficemojo.com/, accessed December 31, 2018.

Notes: *Winner of the Academy Award for Best Visual Effects.

**Winner of the Academy Award for Best Animated Features. 


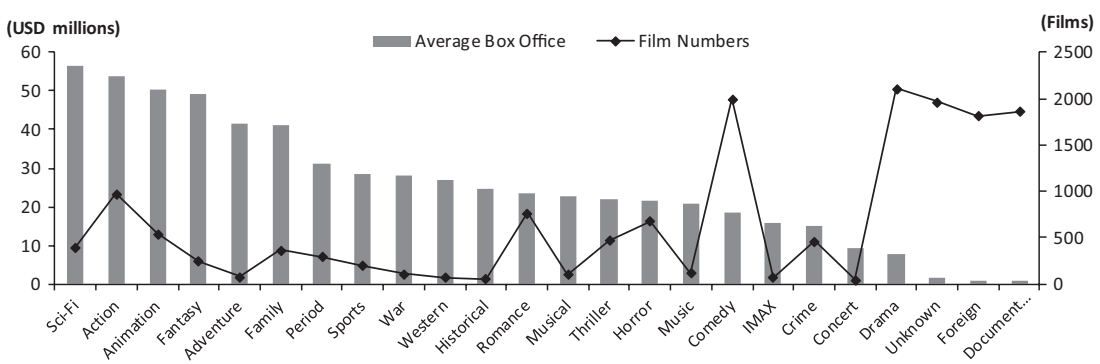

Figure 1.8 Number of major types and average box office receipts in the North American film market, 1982-2018.

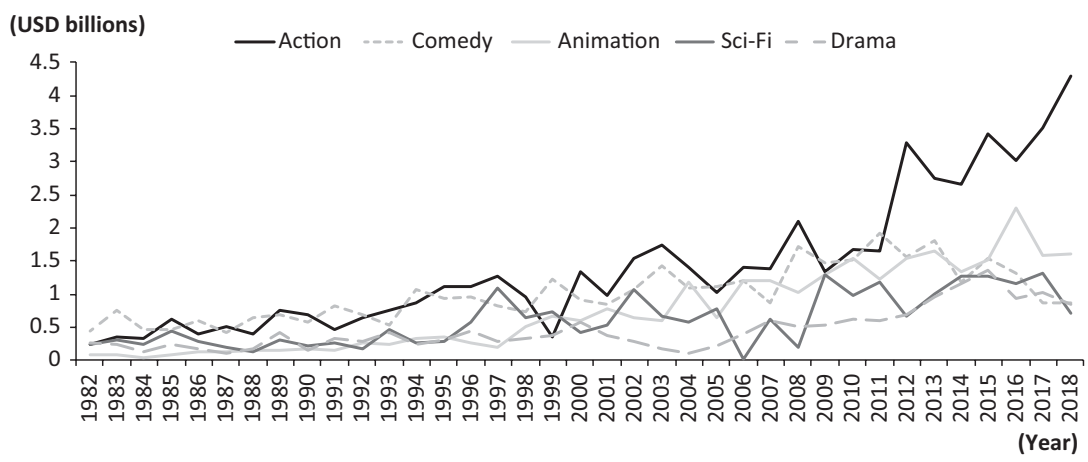

Figure 1.9 North American film market total box office trend of main film types, 1982-2018.

unprecedented innovation and great impact, became the symbol of social popular culture and gained an important role in the film industry. Star Wars, Star Trek, Terminator, Alien, Back to the Future, Jurassic Park, The Matrix, Transformers, Rise of the Planet of the Apes and other series of sci-fi movies have won great successes at the box office, constantly renewing the box office record. The global box office of Avatar reached US $\$ 2.788$ billion, making it a great success in the global film industry. The director James Cameron believes that sci-fi movies tell stories of human beings' love and hate for the future of technology. The main attraction of sci-fi films is that it brings a new sense of freshness, and also curiosity about the future and concern for our own destiny.

Sci-fi movies are the main film genre that presents computer-generated images, paying more attention to special effects and spectacular visual presentations. From the earliest Le Voyage dans la Lune, through Earth vs. the Flying Saucers, to Transformers, the new technology continues to strengthen this genre to show new power, new form and new spectacle to the world. 
Despite the fact that computer-generated images can be used in all types of modern movies, sci-fi films are still the main genre for special effects technology and spectacular images. A spectacle is usually an event designed specifically for the general public, not for individuals, but for a large number of viewers. Stars, colors, sound design, widescreen and 3D all create a sense of pleasure in a film, but the visual spectacle in sci-fi movies is the specific element of its success. Props, sets and costumes are often enhanced with the help of special effects techniques. Special effects technology sits on the boundary between reality and fantasy. This creates a stunning picture of the world and also makes such a world seem authentic. The sci-fi film realizes the visual and speculative narrative through the novel sci-fi concept and its conceptual design, and creates a stunning visual spectacle using digital production technology.

\section{Reference}

Chunjuan, W. (2015). Entertainment Consumption Experience. Beijing: China Economic Publishing House. 